\title{
The Relation Between IGF-1 Levels and Fasting Blood Glucose in Obese Women
}

\author{
Zakaria Sendy Wardana ${ }^{1 *}$, Gadis Meinar Sari' ${ }^{1}$, Damayanti Tinduh ${ }^{2}$ \\ ${ }^{1,}$ Universitas Airlangga, Surabaya, Indonesia \\ ${ }^{2}$ Dr. Soetomo General Hospital, Surabaya, Indonesia \\ zakariasendywardana@gmail.com
}

\begin{abstract}
Obesity is one of the causes of metabolic disorders such as insulin resistance, resulting in an increase in blood glucose levels. In obesity, hyperinsulinemia due to peripheral insulin resistance binds to Insuline-Like Growth Factor-1 Receptors (IGF-1R), resulting in decreased circulation of Insulin-Like Growth Factor Binding Protein-1 (IGFBP-1) resulting in IGF-1 levels free in the blood increases. The purpose of this study was to analyze the relation between levels of insuline-like growth factor-1 (IGF-1) and Fasting Blood Glucose (FBG) in obese women. This study used a cross sectional study method using 39 obese women aged 19-22 years old, Body Mass Index (BMI) 25-35 kg / m2 and Percentage Body Fat (PBF) above 30\%, normal blood pressure, heart rate normal rest and normal Hemoglobin $(\mathrm{Hb})$. IGF-1 levels were measured using the Enzym Link Immunosorbent Assay (ELISA) method, while the FBG measurements used ACCU-CHEK ${ }^{\circledR}$ Performance. Data analysis techniques used the Pearson Correlation test with the Statistical Package for Social Science (SPSS). The results obtained an average level of IGF-1 $(11,530 \pm 4,397) \mathrm{ng} / \mathrm{mL}$ and an average FBG $(90,153 \pm 6,659) \mathrm{mg} / \mathrm{dL} \quad(\mathrm{r}=0.379)$ and $(\mathrm{p}=0.017)$. Based on the results of the study, it's concluded that there is a positive correlation of IGF-1 levels with FBG in obese women. Further research is needed to explain the physiological mechanism of the relation between IGF-1 and FBG in more detail.
\end{abstract}

Keywords: IGF-1 levels, Fasting blood glucose, Obese women. 


\section{STRADA Jurnal Ilmiah Kesehatan}

DOI: $10.30994 /$ sjik.v9i1.276

ISSN: 2252-3847 (print); 2614-350X (online)

Vol.9 No.1. May 2020. Page.140-146

\section{BACKGROUND}

Changes in nutrition and lifestyle have provoked an increase in the prevalence of obesity. ${ }^{1}$ Obesity is an excess of fat content in adipose tissue. The limit for obesity is generally overweight more than $20 \%$ of the normal standard. Obesity is also defined as a consequence of calorie intake that exceeds the number of calories burned by the body through metabolic processes. ${ }^{2}$ Obesity is a problem all over the world both in developed and developing countries, with prevalence rates increasing so rapidly. ${ }^{3}$ Obesity is a dangerous condition, with prevalence of $20 \% .{ }^{4}$ Based on data from the World Health Organization (WHO) (2016) that more than 1.9 billion people aged over 18 years old are overweight and 650 million of them are obese. ${ }^{5}$ Even according to the results of previous studies showed that in worldwide, the proportion of adults with a Body Mass Index (BMI) of $25 \mathrm{~kg} / \mathrm{m} 2$ or greater is $36.9 \%$ in men and $38 \%$ in women. ${ }^{6}$ This case needs a serious attention.

The impact of obesity according to the Center of Disease Control and Prevention (CDC) (2016) explained that severe obesity (morbid obesity) or long-term obesity can lead to serious medical conditions, increase the risk of impaired glucose tolerance, insulin resistance, type- 2 diabetes mellitus, coronary heart disease, several types of cancers such as endometrial, breast, or colon cancer, hypertension, cholesterol, liver disorders and so on. ${ }^{7}$ In fact, the association of obesity that causes type-2 diabetes mellitus becomes a health problem in 300 million people globally by $2030 .^{8}$ According to the results of previous studies explained that obesity also has an impact on breathing, such as asthma and sleep apnea, joint problems and musculoskeletal discomfort, psychological problems such as anxiety and depression, lowering self-esteem and reducing quality of life and social problems such as bullying and stigma. ${ }^{9}$

Obesity is one of the causes of metabolic disorders such as insulin resistance, resulting in an increase in blood glucose levels. ${ }^{3,4}$ In addition, obesity also affects the secretion of Insuline-Like Growth Factor-1 (IGF-1). In obesity, hyper-insulinemia due to peripheral insulin resistance binds to Insuline-Like Growth Factor-1 Receptors (IGF-1R), resulting in decreased circulation of Insulin-Like Growth Factor Binding Protein-1 (IGFBP1) resulting in IGF-1 levels free in the blood increases. ${ }^{10}$ IGF-1 is a hormone that has the same molecular structure as insulin. This hormone functions as an intermediary against growth hormones, triggers amino acid uptake, protein synthesis and utilization of glucose use, especially in the process of growth and regulation of anabolic function in adults. ${ }^{11,12}$ Production of this hormone is largely in the liver and regulated by Growth Hormone (GH ) .${ }^{13}$ IGF-1 can be synthesized by endocrine, paracrine and autocrine mechanisms. ${ }^{14}$ IGF-1 can stimulate the growth of almost all cells in the body, such as muscle, cartilage, bone, liver and kidney. ${ }^{15}$ The above explanation shows that obesity can affect levels of IGF-1 and blood glucose levels.

Based on the results of previous studies, it's showed a significant correlation between obesity and fasting blood glucose (FBG). ${ }^{3}$ Insulin plays an important role in maintaining normal blood glucose levels, and IGF-I exerts a complementary effect on glucose regulation. ${ }^{1}$ IGF-1 levels indicate value the rate is lower in obese women than in overweight. ${ }^{16}$ However, the physiological mechanism of the relationship between IGF-1 and FBG in obesity remains unclear. Based on this background, the purpose of this study is to analyze the relation between IGF-1 levels and FBG in obese women. 


\section{STRADA Jurnal Ilmiah Kesehatan}

DOI: $10.30994 /$ sjik.v9i1.276

ISSN: 2252-3847 (print); 2614-350X (online)

Vol.9 No.1. May 2020. Page.140-146

\section{METHOD}

This study used a cross sectional study method using 39 obese women aged 19-22 years old, Body Mass Index (BMI) 25-35 kg / m2 and Percentage Body Fat (PBF) above $30 \%$, normal blood pressure, heart rate normal rest and normal hemoglobin ( $\mathrm{Hb})$. All of the research procedures were approved by the Medical Research Ethics Commission of the Faculty of Medicine, Airlangga University, Surabaya number 81 / EC / KEPK / FKUA / 2020.

Blood sampling was done in $4 \mathrm{ml}$ cubital veins. ${ }^{17,18}$ Blood sampling was carried out after 12 hours of fasting. ${ }^{19}$ The blood was in a centrifuge for 10 minutes at a speed of 3000 $\mathrm{rpm}$. The serum was separated and stored at $-20^{\circ} \mathrm{C}$ for analysis of IGF-1 levels the following day. Blood sampling was carried out at 07.00-09.00 WIB. Measurement of IGF-1 levels using the ELISA kit (Catalog No. E-EL-H0086; Elabscience, Inc., China, 2019) with a standard curve range of 1.56-100 ng / mL and IGF-1 sensitivity levels in the kit $0.94 \mathrm{ng} /$ mL. FBG measurements used ACCU-CHEK (ACCU-CHEK® Performa, Mannheim, Germany) with a unit of concentration of $\mathrm{mg} / \mathrm{dL}$. Hb measurement used Easy Touch (Easy Touch GCHb, Taiwan) with g / dL concentration unit.

Height measurements used a stadiometer (SECA, Chino, CA). Measurement of body weight, BMI and PBF used TANITA (Body Composition Analyzer DC3607601 (2) -1604 FA, TANITA Corporation of America, Inc.). Measurement of blood pressure used a digital blood pressure meter (OMRON Model HEM-7130 L, Omron Co.). Heart rate monitoring used Polar (Polar H10 Heart Rate Sensor, USA, Inc.).

Subject taking techniques used consecutive sampling techniques. Statistical analysis using statistical software packages for social science (SPSS). The normality test uses the Shapiro-Wilk test. Data that were normally distributed were tested using Pearson correlation with a significant level $(\mathrm{P}<0.05)$. All data are displayed with mean $\pm \mathrm{SD}$.

\section{RESULT}

The results of the descriptive analysis of the characteristics of the research subjects and the results of the correlation analysis between IGF-1 and FBG can be seen in tables 1 and 2

Table 1. Results of descriptive analyze of research subject characteristics

\begin{tabular}{lccc}
\hline \multicolumn{1}{c}{ Variable } & n & Mean & Std. Deviation \\
\hline Age (years) & 39 & 20.743 & 0.992 \\
\hline Height $(\mathrm{m})$ & 39 & 1.569 & 0.046 \\
\hline Weight $(\mathrm{kg})$ & 39 & 70.982 & 7.283 \\
\hline Body Mass Index $\left(\mathrm{kg} / \mathrm{m}^{2}\right)$ & 39 & 28.805 & 2.289 \\
\hline Percentage Body Fat $(\%)$ & 39 & 43.589 & 3.213 \\
\hline $\begin{array}{l}\text { Systolic Blood Pressure } \\
\text { (mmHg) }\end{array}$ & 39 & 114.359 & 5.023 \\
\hline $\begin{array}{l}\text { Diastole Blood Pressure } \\
\text { (mmHg) }\end{array}$ & 39 & 75.641 & 5.023 \\
\hline Resting Heart Rate (bpm) & 39 & 75.538 & 7.707 \\
\hline Hemoglobin (g/dL) & 39 & 14.882 & 1.233 \\
\hline
\end{tabular}




\section{STRADA Jurnal Ilmiah Kesehatan}

DOI: $10.30994 /$ sjik.v9i1.276

ISSN: 2252-3847 (print); 2614-350X (online)

Vol.9 No.1. May 2020. Page.140-146

Tabel 2. Korelasi Antara Kadar IGF-1 dengan FBG

\begin{tabular}{|c|c|c|c|c|}
\hline Variable & $\mathbf{n}$ & Mean士SD & Pearson $r$ & $P$-value \\
\hline IGF-1 (ng/mL) & 39 & $11.530 \pm 4.397$ & \multirow{2}{*}{0.379} & \multirow{2}{*}{$0.017^{*}$} \\
\hline FBG (mg/dL) & 39 & $90.153 \pm 6.659$ & & \\
\hline
\end{tabular}

Based on table 2 the Pearson correlation test results show that there is a correlation between IGF-1 levels and FBG in obese female subjects with a positive correlation direction $(r=0.379)$ and $(p=0.017)$.

\section{DISCUSSION}

Based on the results of the study, it's showed that there is a correlation between IGF1 levels and FBG in obese female subjects with a positive correlation direction. It is likely due to the state of obesity affecting the secretion of IGF-1 levels. According to previous studies concluded that the average value of IGF-1 levels in obese women is lower than overweight. ${ }^{16}$ Insulin-like Growth Factor-1 (IGF-1), also called somatomedin C, and is a protein in humans coded by the IGF gene. ${ }^{13}$ IGF-1 is a hormone that has the same molecular structure as insulin. This hormone functions as an intermediary against growth hormones, triggers amino acid uptake, protein synthesis and utilization of glucose, especially in the process of growth and regulation of anabolic function in adults. ${ }^{11,12}$ IGF- 1 consists of 70 amino acids in a single chain with three bridges intramolecular disulfide. The production of this hormone is mostly in the liver as an endocrine (systemic) hormone, but it is also locally produced paracrine and autocrine. ${ }^{14}$ The normal level of this hormone in humans is 150-250 $\mu \mathrm{g} / 1$. The factor that stimulates IGF-1 secretion is Growth Hormone (GH). IGF-1 is then known to stimulate the growth of almost all cells in the body, such as muscle, cartilage, bone, liver and kidney. ${ }^{15}$ IGF-1 is released in the liver and binds to IGF-1R in cells, thereby causing cell growth stimulation and inhibition of death cell. This compound is anabolic and has the effect of increasing nitrogen retention and protein synthesis. IGF-1 is able to encourage the growth of new muscle cells, protect brain neurons and promote the growth of new motor neurons. IGF-1 is also responsible for the production of connective tissue, the formation of collagen, and helps in repair of cartilage. ${ }^{20}$ IGF-1 works in conjunction with other hormone axes which are very important in normal metabolism. In the case of obesity, hyper insulinemia due to peripheral insulin resistance will bind to IGF-1 receptors (IGF$1 \mathrm{R})$, resulting in decreased IGFBP-1 circulation which results in IGF-1 levels also decreasing. ${ }^{10}$ The above explanation shows that obese people have decreased IGF-1 -1 .

The results also showed that obesity has a correlation with FBG levels. Previous studies have also found similar results that there is a significant correlation between obesity and fasting blood glucose (FBG) levels. ${ }^{3}$ The correlation between obesity and FBG is likely due to the condition of obesity which affects FBG levels. Humans have a system for regulating blood glucose levels that involves the liver, extra hepatic tissues and hormones. When blood glucose concentration increases, the hormone insulin will be secreted to reduce blood glucose concentration to normal levels. When the blood glucose concentration decreases, glucagon will be secreted so that the increased blood glucose level can become normal. ${ }^{21,22}$ However, in someone who is obese in his body there is accumulation of excess fat. The fat tissue is an active endocrine tissue that can release adipose cytokines. This adipose cytokine has a proinflammatory effect and can disrupt the insulin signaling pathway which can then end in a state of insulin resistance. This situation causes an increase in blood 


\section{STRADA Jurnal Ilmiah Kesehatan}

DOI: $10.30994 /$ sjik.v9i1.276

glucose levels in a person. ${ }^{23}$ In a state of obesity there is a decrease in adiponectin and an increase in free fatty acids that are opposite the effects of insulin, causing a decrease in insulin sensitivity or insulin resistance. Fatty acids and some other metabolites activate protein kinase and damage insulin signaling by increasing serine phosphorylation which is inhibitory from Insulin Receptor Subsrate (IRS), thus causing insulin resistance. In insulin resistance an increase in glucose production and a decrease in glucose use resulting in an increase in blood sugar levels. ${ }^{3}$

This study shows a positive correlation between IGF-1 and FBG. This result is supported by an explanation of the statement from previous studies that insulin plays an important role in the maintenance of normal blood glucose levels, and IGF-I exert a complementary effect on glucose regulation. ${ }^{1}$ IGF-1 is a growth factor that has an important role in normal tissue growth and body metabolism. In addition, IGF-1 has been shown to play a role in the process of glucose homeostasis, which decreases glucose levels and the role of insulin sensitivity. ${ }^{24}$ Specifically, IGF-1 is a polypeptide hormone that has the same structure and function as insulin. Research in mice shows that IGF-1 in the periphery increases glucose uptake and functionally activates IGF1R in mouse bone muscle causing insulin resistance. ${ }^{25}$ IGF-1 is involved in glucose proliferation, differentiation and regulation, through activation of signaling pathways including RAS / RAF / MEK and PI3K / AKT.1 Although insulin and IGF-I play different physiological roles, they both share some of the same signaling pathways. IGF-I can act independently of insulin or increase the effect of insulin. Activation of phosphoinositide 3-kinase (PI3K) and the AKT pathway regulates metabolism. Once insulin or IGF binds to the receptor, the receptor will be autophosphorylation. The resulting phosphotyrosin motif serves as a docking site for the insulin receptor substrate (IRS). The Bound IRS is then a phosphorylated generator docking site for PI3K, which results in the conversion of PIP2 to PIP3. PIP3 recruits AKT to plasma membrane, because AKT has a domain that interacts directly with PIP3. AKT is needed for insulin which is stimulated by glucose transport. Namely Glucose Transporter Protein-4 (GLUT4) is finally trans located from intracellular compartment to the plasma membrane, which results in increased blood glucose absorption. Based on these explanations, it can be concluded that IGF-1 has a correlation with FBG.

\section{CONCLUSION}

Based on the results of the study, it's concluded that there is a positive correlation of IGF-1 levels with FBG in obese women. Based on the results of the study it is recommended to conduct further research using subject in underweight, normal weight, overweight and obesity to see the correlation of IGF-1 levels with FBG. Further research is needed to explain the physiological mechanism of the relation between IGF-1 and FBG in more detail.

\section{REFERENCES}

1. Haywood NJ, Slater TA, Mattews CJ, Wheatcroft SB. The Insulin Like Growth Factor and Binding Protein Family:Novel Therapeutic Targets in Obesity \& Diabetes. Molecular Metabolism, 2018;19(2019):86-96. https://doi.org/10.1016/j.molmet.2018.10.008.

2. Sherwood L. Fisiologi Manusia dari Sel ke Sistem Edisi 8. Jakarta: EGC; 2014. 


\section{STRADA Jurnal Ilmiah Kesehatan}

DOI: $10.30994 /$ sjik.v9i1.276

ISSN: 2252-3847 (print); 2614-350X (online)

Vol.9 No.1. May 2020. Page.140-146

3. Polii RC, Kepel BJ, Bodhi W. and Manampiring AE. Hubungan kadar glukosa darah puasa dengan obesitas pada remaja di Kecamatan Bolangitang Barat Kabupaten Bolaang Mongondow Utara. Jurnal e-Biomedik (eBm), 2016;4(2):1-6.

4. Pasquali R, Casanueva F, Haluzik M, Huisteinjn LV, Ledoux S, Monteiro MP, Salvador J, Santini F, Toplak H. and Dekkers, OM. European Society of Endocrinology Clinical Practice Gusidline: Endocrine Work-Up in Obesity. European Journal of Endocrinology, 2020;182(1):G1-G32. https://doi.org/10.1530/EJE19-0893.

5. World Health Organization (WHO). Obesity and Overweight; 2016. Retrieved April 5, 2020, from WHO: http://www.who.int/mediacentre/factsheets/fs311/en/.

6. Ng M, Fleming T, Robinson M, Thomson B, Graetz N, Margono C, et al. Global, regional, and national prevalence of overweight and obesity in children and adults during 1980-2013: a systematic analysis for the Global Burden of Disease Study 2013. Lancet, 2014; 384(9945):766-781. https://doi.org/10.1016/S0140-6736(14)60460-8.

7. Centers for Disease Control ands Prevention (CDC). Childhood Obesity Causes \& Consequences Overweight \& Obesity. Retrieved April 3, 2020, from Centers for Disease Control and Prevention; 2016. https://www.cdc.gov/obesity/childhood/causes.html.

8. Wild S, Roglic G, Green A, Sicree R. and King H. Estimates for the year 2000 and projections for 2030. Diabetes Care, 2004;27(5):1047e1053. https://doi.org/10.2337/diacare.27.5.1047.

9. Bass R. and Eneli I. Severe childhood obesity: An under-recognized and growing health problem. Postgraduate Medical Journal, 2014;91(1081):639-645. https://doi.org/10.1136/postgradmedj-2014-133033.

10. Lewitt M, Dent M. and Hall K. The Insulin-Like Growth Factor System in Obesity, Insulin Resistance and Type 2 Diabetes Mellitus. Journal of Clinical Medicine, 2014;3(4):1561-1574. https://doi.org/10.3390/jcm3041561.

11. Alvarez-Nava F. and Lanes R. GH/IGF-1 signaling and current knowledge of epigenetics; a review and considerations on possible therapeutic options. International Journal of Molecular Science, 2017;18(10):E1624. https://doi.org/10.3390/ijms18101624.

12. Guo J, Xie J, Zhou B, Gaman M-A, Kord-Varkaneh H, Clark CCT, Salehi-Sahlabadi A, Li Y, Han X, Hao Y. and Liang Y. The influence of zinc supplementation on IGF-1 levels in humans: A systematic review and meta-analysis. Journal of King Saud University - Science, 2020. https://doi.org/10.1016/j.jksus.2020.01.018.

13. TaeHo Kim, Chang JS, Kim H, Lee KH. and Kong ID. Intense Walking Exercise Affects Serum IGF-1 and IGFBP3. Journal of Lifestyle Medicine, 2015;5(1):21-25. http://dx.doi.org/10.15280/jlm.2015.5.1.21.

14. Stein AM, Silva TMV, Coelho FGM, Arantes FJ, Costa JLS, Teodoro L. and SantosGalduróz RF. Physical exercise, IGF-1 and cognition A systematic review of experimental studies in the elderly. Dement Neuropsychol, 2018;12(2):114-122. http://dx.doi.org/10.1590/1980-57642018dn12-020003.

15. Laviola L, Natalicchio A. and Giorgino F. The IGF-1 signaling pathway. Curr Pharm Des, 2007;13(7):663-669.

16. Frystyk J, Brick DJ, Gerweck AV, Utz AL. and Miller KK. Bioactive Insulin-Like Growth Factor-I in Obesity. J Clin Endocrinol Metab, 2009;94(8):3093-3097.

17. Mannerkorpi K, Landin-Wilhelmsen K, Larsson A, Cider A, Arodell O. and Bjersing JL. Acute effects of physical exercise on the serum insulin-like growth factor system in 


\section{STRADA Jurnal Ilmiah Kesehatan}

DOI: $\underline{10.30994 / \text { sjik.v9i1.276 }}$

women with fibromyalgia. BMC Musculoskeletal Disorders, 2017;18(37):1-8. https://doi.org/10.1186/s12891-017-1402-y.

18. Daskalopoulou SS, Daskalopoulou SS, Cooke AB, Gomez YH, Mutter AF, Filippaios A, Mesfum ET. and Mantzoros CS. Plasma irisin levels progressively increase in response to increasing exercise workloads in young, healthy, active subjects. European Journal of Endocrinology, 2014;171(3):343-352. https://doi.org/10.1530/EJE-14-0204.

19. Elizondo-Montemayor L, Silva-Platas C, Torres-Quintanilla A, Rodríguez-López C, Ruiz-Esparza GU, Reyes-Mendoza E. and Garcia-Rivas G. Association of Irisin Plasma Levels with Anthropometric Parameters in Children with Underweight, Normal Weight, Overweight, and Obesity. BioMed Research International, 2017; Vol. 2017, Article ID 2628968:1-11. https://doi.org/10.1155/2017/2628968.

20. Rincon M, Muzumdar R, Atzmon G. and Barzilai N. The paradox of the insulin/IGF-1 signaling pathway in longetivity. Mech Ageing Dev, 2004;125(6):397-403.

21. Guyton AC. and Hall JE. Buku ajar fisiologi kedokteran. Edisi ke 27. Rachman YL, Hartanto H, Novrianti A, Wulandari, editor edisi bahasa Indonesia. Jakarta: ECG; 2012.

22. Bender AB. and Mayes PA. Glikolisis dan Oksidasi Piruvat. In: Murray RK, Granner DK, Rodwell VW, editors. Biokimia Harper. Edisi ke 27. Pendit BU, alih bahasa Indonesia. Wulandari N, editor edisi bahasa Indonesia. Jakarta: buku kedokteran ECG; 2009.

23. Fadilah A, Putri Y, Decroli E. and Nasrul E. Artikel Penelitian Hubungan Derajat Obesitas dengan Kadar Gula Darah Puasa pada Masyarakat di Kelurahan Batung Taba dan Kelurahan Korong Gadang, Kota Padang. J Kesehatan, 2015;4(3):707-711.

24. Nabila R, Widyastuti N. and Murbani EA. Hubungan Lingkar Pergelangan Tangan Dengan Kadar Glukusa Darah Wanita Obesitas Usia 40-55 Tahun. Journal of Nutrition College, 2018;7(2): 92-99. http://ejournal3.undip.ac.id/index.php/jnc/.

25. Drogan D, Schulze MB, Boeing H. and Pischon T. Original Contribution Insulin-Like Growth Factor 1 and Insulin Like Growth Factor - Binding Protein 3 in Relation to the Risk of Type 2 Diabetes Mellitus: Results the EPIC - Potsdam Study. Am J Epidemiol, 2016;183(6):553-560. 